\title{
Private Sponsorship: Complementary or Conflicting Interests?
}

\author{
SHAUNA LABMAN
}

\section{Abstract}

Canada's Private Sponsorship of Refugees Program commenced before the Indochinese refugee flow began, and it has continued for almost 40 years since it subsided. Although conceived of as a complementary partnership, private sponsorship plays out more as a tug-of-war between the conflicting interests of government and sponsors over selection control and numbers. While guided by additionality, sponsors have been confronted with administrative and regulatory changes that challenge them to do more with less, and the fear that overall Canadian resettlement will reduce if their efforts are not expanded. A federal election and change of government in October 2015 may have reset government-sponsor relations but highlights the vulnerability and interpretative malleability of the program. With the pillars of the Indochinese and now Syrian resettlement efforts bookending the analysis, the article provides a historical and contextual understanding of recent changes to private sponsorship and the tensions and conflicting interests in maintaining a voluntary program premised on the resettlement of additional refugees.

\section{Résumé}

Le Programme de parrainage privé de réfugiés du Canada avait débuté avant l'influx des réfugiés indochinois, et a continué d'exister pendant presque 40 ans depuis la fin de cet influx. Le parrainage privé, bien que conçu comme un partenariat complémentaire, se manifeste en réalité plutôt comme un tiraillement constant entre les intérêts contradictoires du gouvernement et ceux des répondants en ce qui concerne la sélection et le nombre de réfugiés. Malgré le fait que les répondants sont régis par le principe d'additionnalité, ils font face à des changements administratifs ainsi que règlementaires qui exigent qu'ils fassent davantage avec moins de ressources, et se trouvent confrontés à la crainte qu'il se produise une réduction générale dans le nombre de réinstallations au Canada s'ils ne redoublent pas l'ampleur de leurs efforts. L'élection fédérale et le changement du gouvernement en octobre 2015 a sans doute relancé les relations entre le gouvernement et les répondants, mais cela souligne en même temps la vulnérabilité ainsi que l'ambiguité d'interprétation qui caractérise le programme. Avec les piliers des initiatives de réinstallation des réfugiés indochinois dans le passé et ceux des réfugiés syriens dans le présent servant comme balises aux deux extrémités de l'analyse, l'article fournit une perspective historique et contextuelle des changements récents au parrainage privé, et des tensions ainsi qu'intérêts contradictoires qui résident dans le maintien d'un programme volontaire fondé sur le principe d'additionnalité pour la réinstallation de réfugiés supplémentaires.

In the meantime, we would ask that all members of the House reach out to private sponsors and sponsorship agreement holders across this country to make sure that we fill the 1,300 places available.

-Chris Alexander Minister of Citizenship and Immigration, 27 February 2014

$\mathrm{P}$ rivate sponsorship is unique to Canada. Created out of the will of individual Canadians to help refugees and those in need, it was made possible through the willingness of Canadian politicians and immigration officials. The formal program was conceived of almost 40 years 
ago as a complement to the Canadian government program of refugee resettlement. Resettlement is itself situated as a voluntary complement to the government's commitment in international and domestic law to the concept of refugee asylum and the principle of non-refoulement. ${ }^{1}$ Resettlement represents the recognition that not all refugees can access asylum and that certain geographic regions face greater refugee flows than others. For private sponsors, their efforts are framed in the concept of "additionality"-making resettlement available to additional refugees beyond government commitments.

This article traces private sponsorship from its origins in advance of the Indochinese crisis of the 1970s to Canada's Syrian resettlement response in December 2015. Sponsors rely on the government to facilitate their sponsorships as much as the government relies on sponsors to contribute to Canada's humanitarian commitments. Yet, as a voluntary program designed through policy and regulation but no legal obligation, there is an interpretative malleability to the government-sponsor relationship that can lead in different directions, depending on the predilections of the government in power. In recent years resettlement and sponsorship experienced more focused government attention than in the program's entire history. Policy and regulatory changes culminated in a state of flux and arguable crisis. Sponsors faced requests to do more with less, and the threat that overall Canadian resettlement would reduce if their efforts were not expanded. The complementarity of the model risks collapse as it is weighed down by conflicting interests and compromise. With the unfolding of the Syrian tragedy and a change in the Canadian government in 2015, the moment of crisis seemingly abated, but maintenance of private sponsorship's complementary role remains the continual challenge. Additionality can too easily devolve into a relationship of over-reliance and dependence.

\section{Beginnings}

Canada was a country of resettlement long before it became a country of asylum. Through the International Refugee Organization, Canada took in over 100,00o resettlement refugees in the late 1940 os. $^{2}$ This was followed by the admis sion of approximately 37,000 refugees from Hungary in 1956 and 1957, 11,000 from Czechoslovakia in 1968, and 7,000 Asians expelled from Uganda in 1972.3 Admissions were based on ad hoc decisions and orders-in-council. ${ }^{4}$ They were also clearly ideological, strategic, and entirely selective. 5 However, alongside these mass movement resettlements, individual Canadians were angling to facilitate admissions on a smaller scale.

Both the Mennonite Central Committee (MCC) and the Jewish Immigrant Aid Services (JIAS) of Canada were founded following the First World War to assist in immigration to Canada. ${ }^{6}$ During the Second World War other religious collaborations followed, such as the Canadian Christian Council for the Resettlement of Refugees (1946), the Approved Church Program (1953), and the National Inter-Faith Immigration Committee (1968), to bring in and support additional refugees and displaced persons.7 These initiatives stood in contrast to Canadian government action on refugee protection. While supporting the United Nations High Commissioner for Refugees (UNHCR) financially since its inception, ${ }^{8}$ playing a lead role in the drafting of the 1951 Convention relating to the Status of Refugees (1951 Convention), ${ }^{9}$ and serving on UNHCR's Executive Committee, Canada did not ratify the 1951 Convention or its 1967 Protocol relating to the Status of Refugees until 4 June 1969. ${ }^{10}$ The Canadian government was reluctant to give up absolute sovereign control of its borders that the 1951 Convention requires for refugee admissions. Nor did Canada consider itself a country of first asylum. ${ }^{11}$

Canada's eventual decision to ratify the 1951 Convention presented an opportunity for broader reform of Canadian refugee law. In Canada, a ratified international treaty must be implemented through domestic law to be enforceable. The Canadian government therefore needed to revise its immigration legislation to reflect Canada's acceptance of the 1951 Convention obligations and announced plans to design a new Immigration Act in September $1973 .{ }^{12}$ The legislative review process presented an opportunity for religious groups to lobby for the formalization of the private sponsorship they essentially already facilitated. In 1973, Joseph Kage, national executive vice-president of JIAs, suggested that in looking to revise the Immigration Act, "consideration be given to provisions which would enable individuals or responsible voluntary social agencies to offer sponsorship or co-sponsorship in deserving cases of refugees or other immigrants, which would come under the category of 'humanitarian immigration."'13 Even earlier, in 1967, Kage was pushing for sponsorship. Commenting on the government's 1966 white paper on immigration, Kage wrote, "We also suggest that consideration be given to provisions which would enable individuals or responsible voluntary social agencies to offer sponsorship or co-sponsorship to deserving cases of refugees." ${ }^{14}$ For the first time in Canadian law, the 1976 Immigration Act contained provisions for the private sponsorship of refugees (PSR) alongside governmentassisted refugees (GARs). ${ }^{15}$

Private sponsorship was structured to occur through a "Group of Five" or through organizations holding "master agreements" with the government that limited the government's direct involvement with sponsoring groups. ${ }^{16}$ The underlying structure of private sponsorship has remained 
relatively consistent over the intervening years. There are close to 100 Sponsorship Agreement Holders (sAHs) across Canada. ${ }^{17}$ What has shifted over time is the nature of the sponsorship applications. The program, as conceived, was to formalize the already occurring sponsorships of known individuals to be supported by groups such as JIAs and the MCC. ${ }^{18}$ The legislation came into force as media attention and public outrage grew over the worsening Indochinese "boat people" crisis of the late 1970s. Government officials used the sponsorship provisions as a means of directing engaged Canadians to action. ${ }^{19}$ Interest exploded, and private sponsorship shifted from the resettlement of fewer than 100 known refugees by the spring of $1979^{20}$ to the resettlement of 34,000 privately sponsored Indochinese between 1979 and $1980 .^{21}$ Unlike the earlier wartime efforts that created the push for the program, the Indochinese sponsorship was primarily a sponsorship of strangers. There was no real Indochinese base in Canada. As the crisis subsided, a thriving sponsorship community had clearly arisen across Canada, but the nature of this sponsorship would shift with the interests of the sponsors.

In 1990 the government commenced a review of the sponsorship program. ${ }^{22}$ The resulting report pointed to concern that the program was turning into a supplementary tool for expanded family reunification. The sponsorship structure permits sponsors to either "name" the individuals they wish to sponsor or accept a referral from a visa officer of an individual requiring sponsorship. The ability to specify an individual for sponsorship is understandably appealing and grew as the sponsoring community itself grew with incoming refugees. Tom Denton notes, "Among the refugee-sponsoring community, the demand for familylinked sponsorships is seen as being effectively without limit, because for every refugee who arrives sponsors estimate that at least two more sponsorship requests are generated." ${ }^{23}$ The access that sponsorship provides to broader family reunification heightened when the government cancelled the Assisted Relative class in 2002. ${ }^{24}$ The Assisted Relative class reached beyond the immediate family class (spouse or partner, dependent child, parent, or grandparent ${ }^{25}$ to include extended relatives (uncle or aunt, brother or sister, nondependent son or daughter, nephew or niece, grandson or granddaughter). ${ }^{26}$ By 2003 some estimates put nominations of extended family or close friends at between 95 and 99 per cent of private sponsorship referrals. ${ }^{27}$ Sponsorship looked drastically different from the Indochinese movement of strangers. Additionality was operating but failing to complement government efforts as intended. Naming refugees to sponsor as opposed to government referrals requires the further step of government approval. There has been a high refusal rate of sponsor-referred names (averaging 49 per cent between 1998 and 2007). ${ }^{28}$ Refusals drain resources without achieving resettlement, further thwarting additionality.

\section{Reclaiming Control and Constraining Sponsorship}

The government made attempts to reclaim control of the sponsorship program while encouraging increased refugee sponsorship, often as a trade-off for government assistance. A series of pilot projects with slightly different parameters of blended responsibility sharing were negotiated between the government and sponsoring groups. Blending of private and public support commenced with Project Focus Afghanistan. The project resettled 1,800 Afghan Ismaili refugees between 1994 and 1998. The government provided the first three months of settlement support, with private sponsors using this time to fundraise for the remaining nine months of support-a 3/9 model. ${ }^{29}$ Sponsors selected the refugees, but the cases were counted as GARs. A Special 3/9 Sponsorship Pilot Program for refugees from the former Yugoslavia was similarly designed but with the referrals coming from the government. ${ }^{\circ}$ With the Sierra Leonean community in 2001, the government offered a $4 / 8$ model where the community could name its own referrals. The Anglican Primate reached a similar agreement with the government in 2009 that likewise followed this $4 / 8$ financial sharing..$^{11} \mathrm{~A}$ blended 3/9 program for Iraqi refugees was announced in March 2011. Another blended 3/9 project with Rainbow Refugee Committee was announced the following week for the sponsorship of lesbian, gay, bisexual, transgendered, and queer/ questioning (LGBTQ) refugees. ${ }^{32}$ This program was extended for an additional two years in March 2015. 33 A further form of blended support, the Joint Assistance Sponsorship (JAs) program, is included with GAR numbers, but private sponsors provide supplemental, non-financial support to vulnerable refugees with special needs. ${ }^{34}$

As the government's agreements with community groups increased, so too did efforts to constrain sponsorship in other directions. The government placed administrative caps on sponsorship submissions by SAHs in 2011 and 2012, with the intended goal of better management. The caps were both global and specific, targeting specific missions (Nairobi, Pretoria, Islamabad, and Cairo), thereby limiting sponsor ability to respond to specific refugees. 35 This was accompanied in December 2011 with regulatory changes to formalize application procedures and limit eligibility for Group of Five and Community Sponsorships to refugees recognized by UNHCR or a state. ${ }^{36}$ Other changes have less directly but still significantly challenged the continuance of private sponsorship. An entire resettlement class, the Source Country class - which recognized certain states where individuals met the refugee definition but were not outside of their home country-was repealed in 2011, highlighting 
the vulnerability of all resettlement programs to shifting government interests. ${ }^{37}$ A reduction in the age of dependents for all immigration classes from under 22 to under 19 , announced in 2013, came into effect 1 August 2014, limiting the family members who attach to a sponsorship. ${ }^{38}$ Whom sponsors could sponsor was increasingly limited.

In addition, in the spring of 2012, the government reformed the Interim Federal Health Program (IFHP) through two orders-in-council. ${ }^{39}$ The origins of the program begin in a 1952 order-in-council designed to address the emergency medical needs of those in refugee-like situations following the Second World War. $4^{\circ}$ While the program evolved and shifted over the following 60 years, in 2012 it provided health-care coverage to protected persons, government-resettled refugees, privately sponsored refugees, refugee claimants, and refused refugee claimants whose negative decisions were under judicial review or appeal or who were awaiting removal from Canada. Coverage extended until provincial or territorial coverage triggered or the individual left Canada. The 2012 reforms created a tiered system of coverage. Most significant for a discussion of resettlement is that before the 2012 reforms, the IFHP provided basic health coverage, as well as supplemental coverage for prescription drugs, dentistry, and vision care for all resettled refugees. The reforms reduced privately sponsored refugees to services only "if they are of an urgent or essential nature," whereas government-assisted refugees retained extended coverage equivalent to that under provincial and territorial benefits. ${ }^{41}$

Hospitality House Refugee Ministry, a leading sponsorship group based in Winnipeg, Manitoba, challenged the reforms in Federal Court, alleging that the order-in-council breached the contract between the sAHs and Citizenship and Immigration Canada (CIC)..$^{2}$ Their underlying concern was that sponsors would now be responsible for the differential health-care costs. ${ }^{43}$ The application failed. Justice O'Reilly found that the agreement did not specify the level of funding to be provided, there was no evidence the order was enacted without regard to sponsors' interests, and even if there was a breach of contract, the breach would give rise to an action for damages but would not invalidate the order by way of application to the Federal Court. Sponsors were left vulnerable to the whim of government change.

While the Hospitality House application was specific to SAHS, another broader Federal Court challenge on the constitutionality of the reforms succeeded in July 2014. Justice Mactavish held the reforms constitute "cruel and unusual treatment" in violation of section 12 of the Canadian Charter of Rights and Freedoms and violate section 15 of the Charter in the differential treatment between refugee claimants from Designated Countries of Origin and those from non-Designated Countries of Origin. The decision gave the federal government four months to remedy the cuts before a declaration of invalidity was triggered. The minister of citizenship and immigration, Chris Alexander, immediately indicated that the decision would be appealed. 44 On 5 November 2014, at the four-month deadline and having been denied a stay, ${ }^{45}$ the government reluctantly instituted a new Federal Health Program, described as "temporary health-care measures . . . consistent with the Federal Court's ruling." 46 The new measures were not as extensive as the pre-2012 changes and remained tiered in the offering of coverage to different refugee categories. The applicants, arguing that the interim measures failed to meet the identified Charter violations, returned to Justice Mactavish requesting further orders for direction and clarification in relation to the 4 July 2014 order as well as an order compelling the government to comply with the judgment. Justice Mactavish held the requests to be beyond her jurisdiction, given the finality of her original ruling. ${ }^{47}$ The interim measures denied privately sponsored refugees coverage for prescription drugs or supplemental health coverage, both of which remained covered for GARs.

\section{Shifting Responsibility}

Seen in their totality, the changes directly to and affecting private sponsorship highlight a clear divide and increasing animosity between refugee advocates and government refugee policy. Private sponsors in particular have been constrained by the recent regulatory and administrative changes. While the government continued to corner sponsors, it also shifted more responsibility and expectation onto the sponsorship community. In CIC's 2009 annual report to Parliament, the minister highlighted a doubling of privately sponsored Iraqi refugees accepted over the following five years. ${ }^{48}$ In 2010, the government prefaced the legislative package to reform Canada's refugee law with an announced increase to Canada's resettlement program of up to 2,500 spaces per year. 49 The increase allotted 500 more spaces to government resettlement, with the remaining 2,000 spaces open for private sponsorship. This made sponsors responsible for 80 per cent of the increase. With the 2012 Budget, the government shifted 1,000 refugee spaces from the government-assisted program to private sponsors. ${ }^{50}$ In 2013, the government announced an initial commitment to resettle 1,300 Syrian refugees by the end of 2014. ${ }^{51}$ This number included 200 GARs, with the remaining 1,100 refugees expected to arrive through private sponsorship over and above the current spaces in the program..$^{2}$ The private sponsorship commitment, made on behalf of sponsors by the Canadian government, was the fifth-largest confirmed pledge for the admission of Syrian refugees received by 
Table 1. GARs/PSRs ranges and landings 2001-2014

\begin{tabular}{|c|c|c|c|c|c|c|c|c|}
\hline \multirow[b]{2}{*}{ Year } & \multicolumn{3}{|c|}{ GAR } & \multicolumn{3}{|c|}{ PSR } & \multicolumn{2}{|c|}{ Total } \\
\hline & Ranges & Actual & $\%$ change & Ranges & Actual & $\%$ change & Actual & $\%$ change \\
\hline 2001 & 7,300 & 8,679 & & $2,800-4,000$ & 3,576 & & 12,255 & \\
\hline 2002 & 7,500 & 7,505 & -14 & $2,900-4,200$ & 3,041 & -15 & 10,546 & -14 \\
\hline 2003 & 7,700 & 7,508 & 0 & $2,900-4,200$ & 3,252 & 7 & 10,760 & 2 \\
\hline 2004 & 7,400 & 7,411 & -1 & $3,400-4,000$ & 3,116 & -4 & 10,527 & -2 \\
\hline 2005 & $7,300-7,500$ & 7,424 & o & $3,000-4,000$ & 2,976 & -4 & 10,400 & -1 \\
\hline 2006 & $7,300-7,500$ & 7,326 & -1 & $3,000-4,000$ & 3,337 & 12 & 10,663 & 3 \\
\hline 2007 & $7,300-7,500$ & 7,572 & 3 & $3,000-4,500$ & 3,588 & 8 & 11,160 & 5 \\
\hline 2008 & $7,300-7,500$ & 7,295 & -4 & $3,300-4,500$ & 3,512 & -2 & 10,807 & -3 \\
\hline 2009 & $7,300-7,500$ & 7,425 & 2 & $3,300-4,500$ & 5,036 & 43 & 12,461 & 15 \\
\hline 2010 & $7,300-8,000$ & 7,264 & -2 & $3,300-6,000$ & 4,833 & -4 & 12,097 & -3 \\
\hline 2011 & $7,400-8,000$ & 7,363 & 1 & $3,800-6,000$ & 5,584 & 16 & 12,947 & 7 \\
\hline 2012 & $7,500-8,000$ & 5,412 & -26 & $4,000-6,000$ & 4,225 & -24 & 9,637 & -26 \\
\hline 2013 & $6,800-7,100$ & 5,661 & 5 & $4,500-6,500$ & 6,269 & 48 & 11,930 & 24 \\
\hline 2014 & $6,900-7,100$ & 7,573 & 34 & $4,500-6,500$ & 4,560 & -27 & 12,133 & 2 \\
\hline
\end{tabular}

Sources: CIC, Summative Evaluation of Sponsorship, 3.2.1 (2001-6 ranges); CIC, 2007-14 annual reports to Parliament on immigration (2007-14 ranges); CIC, Facts \& Figures 2010 (2001-5); CIC, Facts \& Figures 2014 (2005-14).

Note: Figures $1-3$ are based on this table.

UNHCR by June 2014, behind pledges by the United States, Germany, Austria, and Sweden.53 The Canadian government promise meanwhile ranked tenth.

Despite a seemingly continual stream of announced increases to refugee resettlement over the past few years, the actual arrival numbers show a decline. The 2010 announcement of a 2,500 increase amounted to a promised expansion of the resettlement program by 20 per cent. Ultimately there was a drop in resettlement numbers by 26 per cent between 2011 and 2012. In its 2013 annual report, the government explained the 2012 numbers: "Many of CIC's visa offices were affected by instability and heightened security concerns in some parts of the Middle East and Africa." 54 Even if this explanation is accepted, by 201142 per cent of resettled refugees were privately sponsored. In comparison, between 2001 and 2008 government resettlement numbers were approximately double private sponsorship numbers, whereas by 2013 the ranges were almost equivalent for each program. The 2013 annual report, did state, "CIC continues to maintain its commitments under the Balanced Refugee Reform Act to increase the annual number of refugees resettled from abroad to as many as 14,500 refugees by 2013." Total 2013 resettlement amounted just over 12,00o, and no similar statement of commitment was made in the 2014 annual report. 55

Government resettlement and private sponsorship from 2001 to 2014 is charted in table 1 , as well as the percentage yearly change in admission. Overall resettlement between the two groups differs by just over 100 admissions between 2001 and 2014, but how the numbers fall between sponsors and the government differs significantly. Between 2001 and 2013, the trend was a general decline in government numbers (from 8,679 in 2001 to 5,661 in 2013), while sponsorship numbers almost doubled (from 3,576 in 2001 to 6,269 in 2013).

A similar graphing of GAR and PSR numbers until 2013 in a Library of Parliament research publication on resettlement surmises, "As most of the government's increase to the resettlement target is allocated to private sponsorship (2,000 out of 2,500 spots), the trends evident in Figure 1 are likely to continue." ${ }^{56}$ And yet, this was more than a "trend." It was an intentional and significant reallocation of resettlement numbers from government to private citizens.

The 2014 numbers show a significant drop (27 per cent) in private sponsorship while government numbers realigned with earlier years, hovering between 7,000 and 8,000. The government can increase quotas and announce grand expansions, but it remains up to individual Canadians to voluntarily take on the personal and financial responsibility to sponsor. The Canadian Council for Refugees (CCR) notes, "Canadians have a range of reasons for getting involved in sponsorship, but often a sense of personal connection with a particular region or individual is key (which is why named sponsorships are so important). It is not so clear how broad the motivation is to resettle refugees based on government priorities, particularly if there is a perception that sponsors 


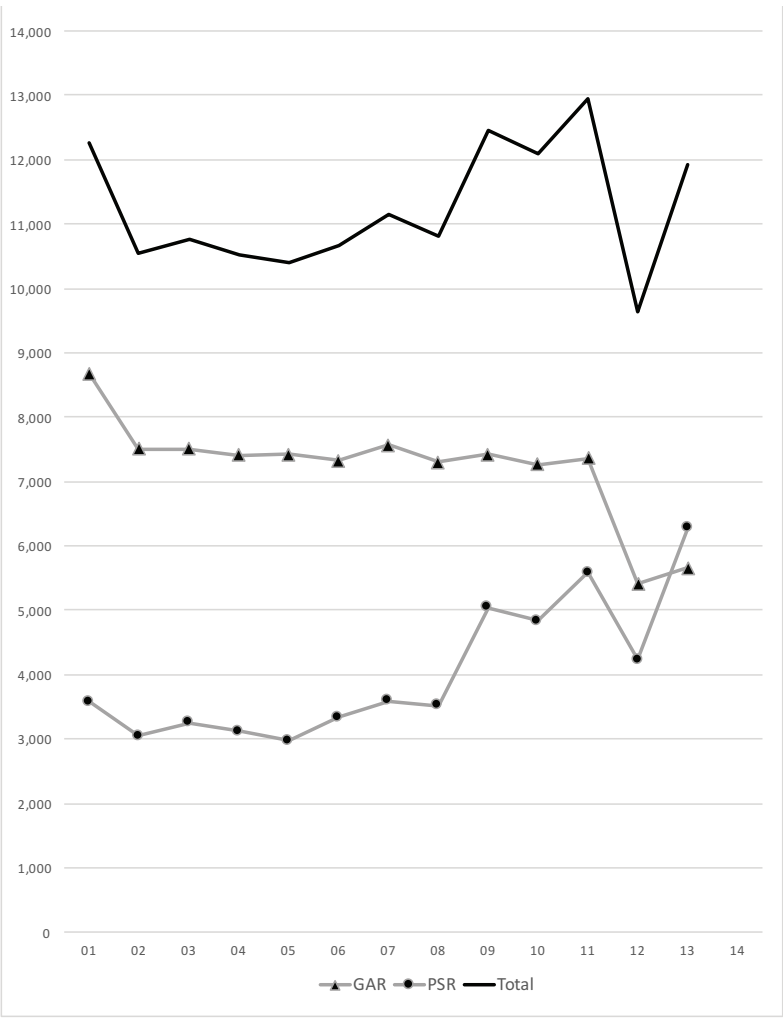

Figure 1. GAR, PSR, and total

are being asked to fill in the gap created by government cutbacks." 57 Additionality depends on the will of sponsors.

A little over a year after the announced doubling of Iraqi refugees, the government offered up the blended 3/9 program for Iraqi refugees, seemingly to encourage the sponsorship it had previously promised and still needing to "fill in the gap." Following the multiple and various pilot projects, the government launched the Blended Visa Office-Referred Program (BVOR) in 2013..$^{8}$ The program increases the amount of government support from earlier pilot projects but takes back the control over naming that many of the earlier blended models left with sponsors. The program matches private sponsors with refugees referred for resettlement by the United Nations under a cost-sharing model where the government splits financial support with sponsors, each covering six months. As well, the referred refugees are "travel-ready," which means that rather than waiting years for processing, refugees arrive in Canada within one to four months.59 Resettled refugees in this category still receive full IFHP coverage. ${ }^{60}$ While constraining private sponsors' ability to sponsor the refugees they choose, the BVOR program offers the carrot enticement of less financial obligation, more support and faster arrivals. But it requires sponsors to bite and sacrifice the principle of naming with a program that further blurs additionality.

In the first year, the plan was to resettle 200 Iraqi, Iranian, Burmese, Eritrean, and Bhutanese refugees through Bvor. ${ }^{61}$ BVOR targets in 2014, increased to 500, were placed not on refugees but on visa offices in Amman, Ankara, Beirut, Cairo, Nairobi, Singapore, and Bogota.62 Actual 2013 numbers totalled 153 and increased to only 177 in 2014. ${ }^{63}$ By 2015, the government goal was to match between 700 and 1,000 refugees with sponsors each year through the program.64 The 1,000 BVor allocation replaced an equivalent number of GARs moved out in the 2012 Budget. ${ }^{65}$ In a five-minute promotional video for the new program put out by CIC, the narrator begins: "The Government of Canada has introduced a unique program to help refugees. The Blended Visa Office-Referred program makes it easier for private sponsors to provide support . . . to refugees in need." The video ends with a refugee speaking directly to the camera: "I want to send message for them. Please, there's many families that are looking for hope to ... to help them." ${ }^{\prime \prime}$ Ostensibly, this message is speaking to private sponsors.

Sponsors are clearly aware of the protection needs of refugees. Engaging in hands-on and direct settlement assistance, they are the voice of support and advocacy in Canada. The program immerses Canadians in the personal experiences of refugees. ${ }^{67}$ Refugees constitute their friends, family, and community. The video's plea, through its own rhetoric and projection of the refugee, is questionable. It implies that it is the responsibility of private Canadian citizens, rather than the Canadian government, to provide the humanitarian response to protection needs. James Hathaway pointedly notes, "The government should not be permitted to make the implementation of its international burden-sharing obligation largely dependent on the goodwill of the private sector." 68 Catherine Dauvergne suggests, "Private sponsorship both allows the government an easy response to domestic pressure to act more humanely and allows it to withdraw from direct responsibility for admission totals ... the obligation is privatized and thus the responsibility of the nation is drastically reduced." 69 These concerns are not new, they are the continual challenge of the government-sponsorship relationship.

When the government added sponsorship provisions into the regulations in the 1970s, church groups expressed concern that "the government intended to use the plan as a means of dumping its responsibilities for refugees onto the private sector."70 In the midst of the Indochinese sponsorship, when the government seemingly reneged on a promise to match private sponsorship on a one-to-one basis, ${ }^{71}$ the Standing Conference of Canadian Organizations 
Concerned for Refugees sent a letter in December 1979 to Prime Minister Joe Clark, Minister of External Affairs Flora MacDonald, Secretary of State David MacDonald, and Immigration Minister Ronald Atkey, stating, "We are not prepared to release the government from its obligations."72 The idea of private sponsorship, from the outset, was one of additionality. Additionality is the shield that protects against the over-reliance and dependence that Hathaway, Dauvergne, and others fear in the privatized offering. Even in 1979 when sponsor-government relations were straining, Employment and Immigration Canada put out a fact sheet for sponsorship that read, "Canadian groups and organizations who are prepared to act as sponsors, supplying the more personalized settlement services needed by displaced and persecuted people, will have a direct influence on the total number of refugees that can come to Canada. This is because refugees assisted in this way are admitted over and above those planned for in the government's annual refugee resettlement plan."73 Government documents continue to recognize this principle of additionality. The Guide to Private Sponsorship states, "Canadian citizens and permanent residents are able to provide additional opportunities for refugees." 74 Yet, after almost 40 years of negotiating their role, sponsors still must reassert additionality.

With low 2014 sponsorship numbers and less than half of the 500 target for Bvors met, fears that overall Canadian resettlement would reduce if sponsor efforts were not expanded seemed well-founded. The goal of additionality risks backfiring into a reduction of resettlement numbers: "If private sponsors are unable to meet the targets set by government for blended sponsorships, it has been suggested that the places will go unfilled. Private sponsors are thus put in the unenviable position of needing to work hard to ensure that refugees don't end up deprived of the opportunity for safety and a new life in Canada. Far from adding to the government's numbers of refugees resettled, private sponsors seem to be responsible for ensuring that the government's numbers are not reduced!"75 The concern with the privatization of a responsibility that rests with the state is heightened by the recollection that private sponsorship is particular to Canada. Resettlement is regarded by UNHCR as not only a tool of protection but as a mechanism for international burden or responsibility sharing..$^{6}$ Sponsorship serves not only as a response to domestic pressure but as a response to other states and international calls. As other governments offer support, is it ever right for the Canadian government to point to its private citizens to answer the call?

\section{Syria}

The current unrelenting flow of refugees from Syria echoes the Indochinese need for a response beyond direct asylum.
It is also a strong and recent example of the tendency for the Canadian government to turn to sponsors in response to both domestic questions on Canada's commitments and international calls for humanitarian assistance. In May 2013, an emergency debate on Syria was conducted in the House of Commons. ${ }^{77}$ Questions on resettlement were raised, but UNHCR had not yet recommended that states engage in this solution. In July 2013, the Canadian government announced its intention that 1,300 Syrian refugees would be resettled to Canada by the end of $2014 .^{78}$ UNHCR had requested the resettlement of urgent and vulnerable cases, and Canada committed to resettle 200 vulnerable refugees through the GAR program in 2013 and 2014. The remainder of the announced commitment, 1,100, was to occur through private sponsorship. The CCR responded, "This is causing some surprise as it is not known that any private sponsors had individually or collectively signalled their capacity to take on this number of sponsorships (which represents a financial responsibility of between $\$ 8$ million and $\$ 12$ million)." 79 The CCR raised concerns at that time regarding the inability of private sponsors to resettle from Turkey where many Syrians had fled ${ }^{80}$ and the additional costs resulting from reduced IFHP coverage. Restrictions on Group of Five sponsorships to recognized refugees prevents these sponsorships during mass refugee flows such as Syrian refugees where UNHCR cannot conduct individual status determinations. SAHs further noted the challenge of such a large sponsorship with no advance warning or consultation prior to the media announcement. ${ }^{81}$ Within a few months of the announcement, the CCR added, "Given the delays and barriers in the private sponsorship program, it is not expected that many privately sponsored Syrian refugees will arrive by end of 2014." ${ }^{82}$

By October 2013, UNHCR issued a call for countries to admit up to 30,000 Syrian refugees by the end of 2014. In early 2014, the Canadian government faced questions in the House of Commons and from media on Canada's resettlement process for Syrians, compared to the commitments of other countries. Immigration Minister Chris Alexander responded by asking that "all members of the House reach out to private sponsors and sponsorship agreement holders across this country to make sure that we fill the 1,300 places available." ${ }^{83}$ Later his press secretary reiterated, "Hundreds of private sponsorship opportunities remain. We encourage sponsorship agreement holders to do their part to help displaced Syrians as well." ${ }^{44}$ The government message made it clear that the finger was pointed at private sponsors. When UNHCR requested that countries resettle more Syrian refugees, asking states to take 100,00o Syrian refugees in 2015 and 2016, the Canadian Immigrant Settlement Sector Alliance urged Canada to commit to 10,000 refugees by $2016 .{ }^{85}$ In response, Minister Alexander talked about how much 
more can been done if the GAR program is combined with "innovative forms of private sponsorship." ${ }^{86}$ Sponsorship was clearly and unapologetically front and centre in the government's approach to Syria.

At the same time sAHs, willing to sponsor despite the lack of notice and increased expenses, were sharing with media their frustrations with sponsorship processing and delays. sAHs indicated that privately sponsored Syrians would not arrive in Canada for two to three years ${ }^{87}$ and complained of the "difficulty and costs associated with the process." ${ }^{8}$ In May 2014, the Syrian Canadian Council asserted that none of 1,300 refugees had made it to Canada and that "private sponsorship is almost impossible." ${ }^{89}$ Processing times for private sponsorship applications in Syria's neighbouring countries ranged from 24 months in Beirut to 43 months in Cairo as of July 2014. ${ }^{\circ 0}$ By the end of June 2014 it was reported that the government was expediting applications for Syrian refugees. ${ }^{91}$

In January 2015, the government announced an additional 10,00o Syrian refugees would be resettled to Canada over the next three years. ${ }^{92}$ In the same announcement, the minister of immigration indicated that since July 2013 more than 1,285 Syrian refugees had been approved for resettlement in Canada and more than 1,075 of those had already arrived by 5 January 2015. These numbers were below the 1,300 promise, even with the government going above their own commitment of 200 and approving the resettlement of 360 Syrians. Private sponsorship numbers were therefore quite high, and significantly above government numbers, but not maximized. Once again, with the announcement of the intended resettlement of 10,00o Syrians over the next three years, the majority of this promise, 60 per cent, was allocated to private sponsorship. Once again, this allocation was made without consulting sponsors. 93

The difficulty with this messaging is that it absolves the government of responsibility for either action or failure. If the numbers are met and the refugees arrive, it is the result of private efforts and not an engaged government response. If the numbers are not met and the refugees do not arrive, blame lands on private sponsors. It has been said that sponsorship is the "political barometer" of refugee support in Canada. ${ }^{94}$ The government itself has acknowledged that "the willingness of so many Canadians to give so generously of their time to assist refugees is a visible demonstration of their commitment to continuing Canada's humanitarian tradition."95 A failure to meet the promised numbers therefore leads not only to fewer refugees receiving protection but to a powerful suggestion that resettlement is neither demanded nor supported by Canadian citizens.

And yet the numbers and financial contributions of Canadians tell a different story. Since 1979, private Canadian sponsors have resettled over 225,00o refugees. Canadian private citizens have resettled more refugees than most governments, ranking fourth behind the United States, Canada and Australia. ${ }^{96}$ In 2006, CCR assessed the annual financial costs of private sponsorship at $\$ 79$ million, with an additional volunteer contribution of over 1,600 hours per refugee family. 97 A "Sponsorship Cost Table" prepared by CIC in 2014 estimates the cost of sponsoring a single individual at $\$ 12,600.9^{8}$

The history of private sponsorship in Canada is a proud one. In 1986, UNHCR awarded the people of Canada the Nansen Medal for their resettlement of the Indochinese. 99 While recipients have included private citizens, politicians, royalty, and organizations, the award to the Canadian people is the only instance where the entire population of a country was recognized. In 2012 Australia initiated a private sponsorship program, the Community Proposal Pilot, ${ }^{100}$ after several years of community advocacy, pointing to the Canadian program as a model. ${ }^{101}$ During the 2013 emergency session in the House of Commons on the crisis in Syria, Paul Dewar reminded members of Parliament of the actions of private sponsors, including his mother, then mayor of Ottawa Marion Dewar, during the Indochinese conflict: "They said we must do more. They held local meetings where people-church groups, bowling teams and others-sponsored refugees, to help those people who were on the high seas and who were being left behind ... It was a grassroots movement that said that as Canadians we have something to do ... We went from having a quota of 8,000 refugees for that year. Because of grass roots and because Canadians mobilized and said we could do something about this, it changed to 60,000." ${ }^{102}$ There is a powerful, convincing, and inspiring pull to the power of private sponsorship and the legacy of the Indochinese resettlement.

Minister of Immigration Chris Alexander wanted Canada's Syrian response to be "one of our large, national efforts in response to a serious crisis on par with our response to the Iraqi crisis, the Vietnamese boat people, Idi Amin in Uganda in 1972 and the 1956 crackdown in Hungary."103 Responses to the crises in Uganda and Hungary predate the sponsorship program and constitute part of the rationale to introduce the regulations. The Indochinese response cemented the program into the Canadian psyche. But the Indochinese resettlement also weaved through two federal elections in Canada and three changes of the political party in power. The minority Liberal government of Pierre Trudeau made the original pledge in 1979 to accept 5,000 refugees. Following a change in government in May 1979, the minority Conservative government led by Joe Clark increased the number to 8,000 and made the later promise of 50,000 through a government-sponsor matching formula 
by the end of $1980 .^{104}$ While sponsorship soared, the government struggled and ultimately opted to maintain the 50,000 resettlement figure by shifting government-assisted refugee spots to privately sponsored refugees. At the time of the government's decision, on 5 December 1979, private sponsorship was at 26,196 refugees, already exceeding its 25,000 portion, whereas the government had resettled only approximately 12,000 refugees. This left a further 11,800 refugees to be resettled, now by private citizens. ${ }^{105}$ In April 1980, the majority Liberal government of Pierre Trudeau re-assumed power. As the new immigration minister, Lloyd Axworthy announced the government's renewed commitment to the Indochinese and increased resettlement targets to 60,000 on 2 April $1980 .{ }^{106}$ The 60,000 target unofficially rebalanced the matching formula between sponsorship and government resettlement. The announcement and swift changes mark the line between politics and law and the role each plays. Shortly after, Gerald Dirks observed, "Any contentiousness associated with refugee admission to Canada in recent years has not arisen due to inadequacies in the legislation but rather has resulted from policy preferences and day-to-day administrative procedures determined by the cabinet and officials of the Employment and Immigration Commission."107 The law was broad and the policy malleable.

Canada's resettlement of Syrian refugees likewise experienced a change of government in the midst of the initiative. Almost a decade of Conservative leadership ended with the election of the majority Liberal government led by Justin Trudeau on 19 October 2015. Resettlement was a key election issue in 2015, receiving far more prominence than during the elections that spanned the Indochinese crisis, or in the nine federal elections and other refugee crises in between. ${ }^{108}$ During the campaign, Justin Trudeau pledged to bring in 25,000 government-assisted Syrian refugees to Canada by the end of 2015, significantly exceeding competing party promises. ${ }^{109}$ By the end of November, the new government revised its election promise and committed to bringing in 10,000 Syrian refugees by the end of 2015, with the remainder arriving by February 2016. ${ }^{110}$ The initial Liberal election promise stood out on its recommitment to GARs, making government promises for government resettlement instead of promises for private sponsors. By November, with the realities of screening and processing refugees setting in, the revised plan relied heavily on private sponsors: "The government also has several thousand applications in processing for privately sponsored refugees (PSRs) under way, and these will be included as part of the commitment."111 At the close of 2015, Minister McCallum announced that just over 6,000 Syrians, mostly privately sponsored Syrians, had arrived in Canada. ${ }^{12}$ While sponsored refugees

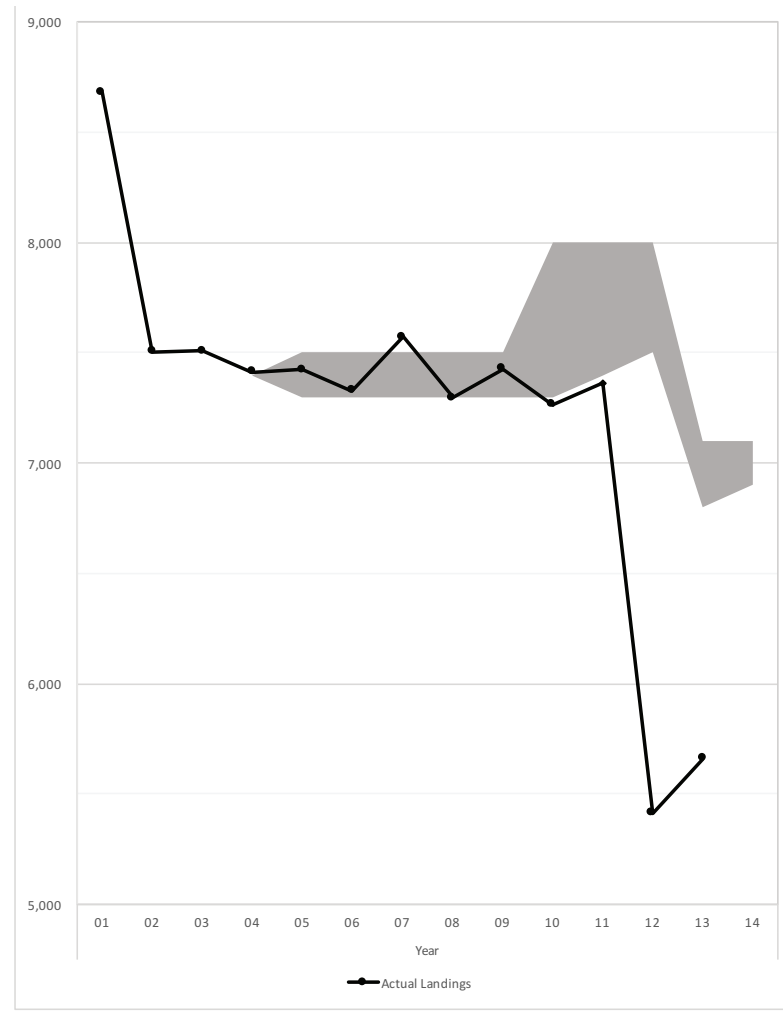

Figure 2. Government-assisted refugees ranges and landings, 2001-2014

will facilitate the February 2016 timeline, the government remains, at the time of writing, committed to 25,00o Syrian GARs in 2016: “The government's commitment to bringing in Syrian refugees will continue in 2016. Given the current initiative includes privately sponsored refugees, this will include taking in more government-assisted refugees (GARs) to reach a total target of 25,000 GARs." 113 What this means for future Canadian resettlement numbers, both GAR and PSR, is difficult to predict.

The previous government's 2010 promise of a 20 per cent increase to resettlement was never met. In 2009 total resettlement numbers sat at 12,461 , while in 2015 the target range was $11,900-15,200 .{ }^{114}$ At the low end, this is no increase at all. At the high end it just passes the 20 per cent increase, but this number includes 1,000 BVOR, a massive leap from the currently released numbers. The BVor targets may now be reached or surpassed as the crisis in Syria has sparked an unprecedented interest in resettlement and private sponsorship reminiscent of the uprising of sponsorship support during the Indochinese crisis of the 1970s. ${ }^{115}$ Syrian resettlement by both the government and private sponsors will significantly raise overall resettlement. It is questionable, though, whether this level of interest and support will continue as sustainable sponsorship support or a singular 


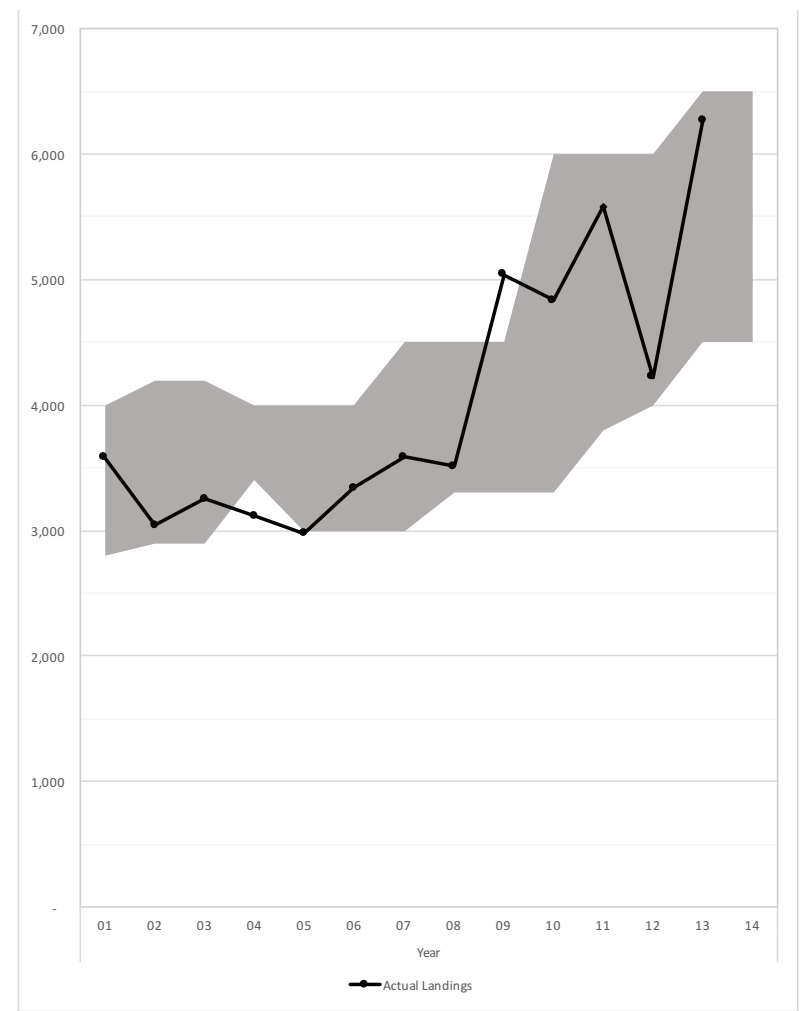

Figure 3. Privately sponsored refugees ranges and landings, 2001-2014

response to a particular moment. Nor, as figures 2 and 3 illustrate, have numbers regularly come close to the upper threshold allowances in the last decade.

There have been reassurances that the Syrian effort will be over and above yearly resettlement targets and recognition that the immense tragedy of the Syrian people cannot overshadow the plight of other refugees in need of protection and resettlement. UNHCR now estimates there are $1,150,300$ refugees in need of resettlement. This is a 50 per cent increase in need from 2012, and projections continue to increase. ${ }^{116}$ Canada's moment of generosity on the Syrian front is a mere drop in the bucket. How Canada will set new targets and balance private and government responsibilities remains to be seen. The Liberal government has indicated that it intends to reverse many of the constraints put on sponsors by the previous government. The mandate letter to the new minister of immigration, refugees and citizenship, John McCallum, includes directions to return the maximum age for dependent children from 19 to 22 , reduce visa application processing times, and fully restore the Interim Federal Health Program. ${ }^{117}$ Whether caps on sponsorship submissions, the limitations on Group of Five and Community Sponsorships, or the shifting focus of the BVOR program continue are unknown.
Sponsorship arose out of a desire to do more. The past decade witnessed a period in which the program operated arguably out of a fear that to do otherwise would amount to less being done. The first comprehensive review of the private sponsorship program in the 1990s cautiously acknowledged, "It remains to be seen whether the resource is renewable, like forests, or whether it more closely resembles gold and, once again mined, is depleted."118 Past policies and numeric shifts suggest a government assumption that sponsorship capacity is unlimited. Sponsors, despite hesitations, complaints, and a frustration at the lack of consultation, continue submitting applications that reaffirm the myth of renewability, even in moments of crisis. If the Syrian crisis brings in new sponsors and resets government-sponsor relations, it is a moment for both sides to assess their role in the program. This piece is not prescriptive, nor are sponsors a single-minded community, but historical understanding and contextual knowledge are necessary to address how to move forward, to reassert additionality, and to maintain incentives for sustainable sponsorship.

\section{Acknowledgments}

This paper benefitted from the exceptional research assistance of Nora Fien and was supported by the University Research Grant Program at the University of Manitoba.

\section{Notes}

1 For a discussion of the general challenge of operating a resettlement program alongside the obligation of asylum, see Shauna Labman, "Queue the Rhetoric: Refugees, Resettlement and Reform," University of New Brunswick Law Journal 62 (2011): 55-63.

2 David Corbett, Canada's Immigration Policy: A Critique (Toronto: University of Toronto Press, 1957), 198-9.

3 Sharryn J. Aiken, "Of Gods and Monsters: National Security and Canadian Refugee Policy," Revue québécoise de droit international 14, no. 2 (2001): 9.

4 Gerald E. Dirks, "A Policy within a Policy: The Identification and Admission of Refugees to Canada," Canadian Journal of Political Science 17, no. 2 (1984): 280; Alan G. Green and David Green, "The Goals of Canada's Immigration Policy: A Historical Perspective," Canadian Journal of Urban Research 13, no. 1 (2004): 102.

5 See Aiken, "Of Gods and Monsters," 9; James C. Hathaway, "Selective Concern: An Overview of Refugee Law in Canada," McGill Law Journal 33, no. 4 (1987-8): 677-8.

6 Howard Adelman, Canada and the Indochinese Refugees (Regina: L.A. Weigl Educational Associates, 1982), 107. An Order in Council, 2 June 1922, permitted Mennonites from the Soviet Union to come to Canada but required that the Canadian Mennonite community take responsibility for the care of the newcomers so that they would 
not become a burden on the state. William Janzen, "The 1979 MCC Canada Master Agreement for the Sponsorship of Refugees in Historical Perspective," Journal of Mennonite Studies 24 (2006): 212.

7 Freda Hawkins, Canada and Immigration: Public Policy and Public Concern (Montreal and Kingston: McGillQueen's University Press, 1972), 304-5.

8 In 1957 Canada became a member of the United Nations Refugee Fund Executive Committee. The Executive Committee of the High Commissioner's Programme was established in 1958 by the Economic and Social Council (ECOSOC) Resolution E/REs/672 (xxv) (30 April 1958), and Canada continued on as a member. UNHCR, "Excom Membership by Date of Admission of Members" (30 June 2009).

9 Laura Madokoro, “Belated Signing': Race-Thinking and Canada's Approach to the 1951 Convention relating to the Status of Refugees" (forthcoming).

10 UNHCR, "States Parties to the Convention relating to the Status of Refugees and the 1967 Protocol," http://www. unhcr.org/protect/PROTECTION/3b73bod63.pdf. Earlier, the 1966 White Paper on Immigration recommended that Canada accede to the 1951 Convention and introduce separate legislation to "help refugees." Department of Manpower and Immigration, White Paper on Immigration (Ottawa: 1966), 54-5.

11 Canada continued to see itself as operating a refugee program directed primarily at resettlement, until the 1990 Annual Report to Parliament on Future Immigration Levels, which acknowledged that it "has become a country of first asylum for thousands of people." Employment and Immigration Canada, Annual Report to Parliament: Immigration Plan for 1991-1995 (Ottawa: EIC, 1990), 5.

12 Office of the Minister of Manpower and Immigration, "Statement by the Honourable Robert Andras, Minister of Manpower and Immigration," 17 Septemeber 1973. Prior to this announcement, a rudimentary system for dealing with resettlement and refugee claims in Canada was implemented through Cabinet documents 27 July 1970 and 16 September 1970 and Operations Memorandum 17 January 1971, amended 19 June 1972. This scheme shaped Canada's response to the Indochinese refugees from May 1975 to December 1978. With thanks to Mike Molloy, former director of Refugee Policy Division, for this point.

13 Joseph Kage, "Stepping Stones towards the New Canadian Immigration Act," Jewish Immigrant Aid Society Information Bulletin no. 347 (20 November 1973), 12.

14 Joseph Kage, "Re-Appraising the Canadian Immigration Policy: An Analysis and Comments on the White Paper on Immigration" (January 1967), 18, Canadian Jewish Congress Charities Committee National Archives.

15 Immigration Act, sc 1976-77, c 52.

16 Barbara Treviranus and Micheal Casasola, "Canada's Private Sponsorship of Refugees Program: A Practitioner's Perspective of Its Past and Future," Journal of International
Migration \& Integration 4 (2003): 184; Janzen, "1979 MCC Canada Master Agreement," 212.

17 Citizenship and Immigration Canada (hereafter CIC), "Private Sponsorship of Refugees Program: Sponsorship Agreement Holders," http://www.cic.gc.ca/english/refugees/sponsor/list-sponsors.asp.

18 The MCC was the first national church body to sign a Master Agreement. Janzen, “1979 MCC Canada Master Agreement," 211.

19 Howard Adelman, "The Policy Maker and the Advocate: Case Studies in Refugee Policy," in Making Knowledge Count: Advocacy and Social Science, ed. Peter HarriesJones (Montreal and Kingston: McGill-Queen's University Press, 1991), 62.

20 Employment and Immigration Canada, Indochinese Refugees: The Canadian Response, 1979 and 1980 (Ottawa: Minister of Supply and Services Canada, 1982), 18.

21 Ibid., 8.

22 Employment and Immigration Canada, "Private Sponsorship of Refugee Program," Refuge 12 (1992): 3.

23 Thomas R. Denton, "Understanding Private Refugee Sponsorship in Manitoba," Journal of International Migration \& Integration 4 (2003): 264.

24 The cancellation of the Assisted Relative category occurred through the repeal of the Immigration Regulations, 1978, SOR/78-172, by the Immigration and Refugee Protection Regulations, soR/2002-227, s 364 (a) that accompanied the introduction of the Immigration and Refugee Protection Act. In a 2004 resolution the Canadian Council for Refugees notes, "Cancellation of the Assisted Relative category has greatly increased the pressure on the Private Sponsorship program." Canadian Council for Refugees, "Assisted Relatives: Resolution number 2" (November 2004), www. ccrweb.ca/en/res/assisted-relatives.

25 Immigration and Refugee Protection Act, sc 2001, c 27, s 12(1); Immigration and Refugee Protection Regulations, $s$ $117(1)$.

26 Immigration Regulations, s 2(1).

27 Denton, "Understanding Private Refugee Sponsorship," 258.

28 CIC, Summative Evaluation of the Private Sponsorship of Refugees Program (2007), 4.0.

29 Ibid., 1.2.1.

30 CIC, A Broader Vision: Immigration Plan (1996 Annual Report to Parliament), (Ottawa: Minister of Supply and Services Canada, 1995), 14.

31 CIC, "Government of Canada and the Anglican Church of Canada Encourage Canadians to Sponsor Refugees," news release, 16 April 2009; CIC, "Canada and Anglican Church Give 50 Refugee Families New Hope," news release, 13 February 2012.

32 CIC, "Government of Canada to Help Gay and Lesbian Refugees Fleeing Persecution," news release, 24 March 2011. 
33 "Rainbow Refugee Assistance Program Extended for 2 Years," свс News, 10 March 2015.

34 Immigration and Refugee Protection Regulations, s 157; CIC, Guide to the Private Sponsorship of Refugees Program (Ottawa: Minister of Public Works and Government Services Canada, 2011), 25.

35 CIC, "Regulations Amending the Immigration and Refugee Protection Regulations and Regulatory Impact Analysis Statement," SOR/2012-225, 146:23 Canada Gazette (9 June 2012).

36 CIC, "Notice Requesting Comments on a Proposed Regulatory Amendment That Will Affect the Private Sponsorship of Refugees Program," 145:50 Canada Gazette (10 December 2011); Immigration and Refugee Protection Regulations, s 153(1)(b).

37 CIC, "Regulations Amending the Immigration and Refugee Protection Regulations and Regulatory Impact Analysis Statement," 145:2 Canada Gazette (19 March 2011).

38 CIC, "Regulations Amending the Immigration and Refugee Protection Regulations and Regulatory Impact Analysis Statement," 147:20 Canada Gazette (18 May 2013); CIC, "Regulations Amending the Immigration and Refugee Protection" 148:13 Canada Gazette (18 June 2014).

39 Order Respecting the Interim Federal Health Program, 2012, si/2012-26 (5 April 2012), 146:9 Canada Gazette (25 April 2012); Order Amending the Order Respecting the Interim Federal Health Program, 2012, SI/2012-49 (28 June 2012) 146:15 Canada Gazette (18 July 2012), replaced the 1957 OIC, effective 30 June 2012.

40 Canadian Doctors for Refugee Care v Canada (AG), 2014 FC 65 para 35.

41 The original Order (si/2012-26) cut coverage for all resettlement refugees, but the amended Order (si/201249) provided that extended coverage was to be granted to government-assisted refugees, while only basic coverage was to be given to privately sponsored refugees.

42 Hospitality House Refugee Ministry Inc v Canada (AG), 2013 FC 543. In November 2015, Citizenship and Immigration Canada was rebranded as Immigration, Refugees and Citizenship Canada (IRCC).

43 Ibid., para 7.

44 Laura Payton, "Federal Government to Appeal Ruling Reversing 'Cruel' Cuts to Refugee Health,” CBC News, 4 July 2014.

45 A request to stay Mactavish's order pending the appeal was denied by Justice Webb on 31 October 2014. Canada (AG) v Canadian Doctors for Refugee Care 2014 FCA 252.

46 CIC, "Temporary Measures for the Interim Federal Health Program" (4 November 2014).

47 Canadian Doctors for Refugee Care v Canada (AG) 2015 FC 149. As discussed below, following the 2015 federal election, the Liberal government announced intentions to fully restore the Interim Federal Health Program. See note 117
48 CIC, Annual Report to Parliament on Immigration, 2009 (Ottawa: CIC, 2009).

49 CIC, "Expanding Canada's Refugee Resettlement Programs," news release, 29 March 2010. Bill C-11, Balanced Refugee Reform Act, was introduced the following day: Hansard: House of Commons Debates, 4oth Parl, 3rd Sess, No 20 (30 March 2010), 1005 (Hon. Jason Kenney, Minister of Citizenship, Immigration and Multiculturalism).

50 Government of Canada, 2012 Federal Budget (29 March 2012) shows the planned reduction in Citizenship and Immigration Canada spending in table 5.1 resulting from this shift.

51 CIC, "Canada to Resettle 1300 Syrian Refugees by End of 2014," news release, 3 July 2013.

52 Ibid.

53 UNHCR, "Finding Solutions for Syrian Refugees: Resettlement and Other Forms of Admission of Syrian Refugees" (11 August 2014).

54 CIC, Annual Report to Parliament on Immigration 2013 (Ottawa: CIC, 2013), 17.

55 CIC, Annual Report to Parliament on Immigration 2014 (Ottawa: CIC, 2014). The 12,00o total includes the GAR and PSR numbers set out below $(11,930)$ as well as 153 Visa Office Referred refugees set out in the 2014 annual report and discussed below.

56 Sandra Elgersma, "Resettling Refugees: Canada's Humanitarian Commitments,” pub. no. 2015-11-E (Ottawa: Library of Parliament Research Publications, 2015).

57 Canadian Council for Refugees, "Important Changes in Canada's Private Sponsorship of Refugees Program" (January 2013).

58 CIC, "Blended Visa Office-Referred Program: Sponsoring Refugees" (30 April 2014).

59 Mennonite Central Committee, "Blended vor Initiative: 2014 Update" (2014); cIC, Guide to the Private Sponsorship, 11.

60 CIC, Information Sheet for Interim Federal Health Program Beneficiaries (14 February 2014), 2.

61 CIC, "Blended Visa Office-Referred Program."

62 CIC, "Government of Canada's Immigration Planning Story: Operational Targets by Office (Non-Economic)" (16 April 2014).

63 CIC, Annual Report 2014: Facts \& Figures 2014.

64 CIC, "Blended Visa Office-Referred Program."

65 CIC, "Operational Bulletin 512 (Modified)-February 12, 2014" (12 February 2014). CIC, "Supplementary Information 2015"; CIC, "Departmental Performance Report (for the Period Ending March 31, 2012)" (30 May 2013).

66 CIC, "How to Sponsor a Refugee: Blended Visa OfficeReferred Program," video (28 April 2014), http://www.cic. gc.ca/english/department/media/multimedia/video/vor/ vor.asp.

67 Treviranus and Casasola, "Canada's Private Sponsorship of Refugees Program," 178; UNHCR, Resettlement Handbook (November 2004), 220. 
68 Hathaway, "Selective Concern," 700.

69 Catherine Dauvergne, Humanitarianism, Identity, and Nation: Migration Laws of Australia and Canada (Vancouver: UBC Press, 2005), 93.

70 Adelman, Canada and the Indochinese Refugees, 85.

71 Adelman, "The Policy Maker," 62; Howard Adelman, "Changes in Policy: Background on the Federal Government Decision to Alter Its Position with Respect to the Indochinese Refugees," in The Indochinese Refugee Movement: The Canadian Experience, ed. Howard Adelman (Toronto: Operation Lifeline, 1979), 23.

72 Ibid.; Adelman, "Changes in Policy," 25. Formed in 1978, the Standing Conference of Organizations Concerned for Refugees was the original name of the Canadian Council for Refugees.

73 Employment and Immigration Canada, "Sponsoring Refugees: Facts for Canadian Groups and Organizations" (July 1979), 2, http://cihs-shic.ca/wp-content/uploads/2015/o3/ Sponsoring-Refugees-Facts-for-Canadian-Groups-andOrganizations.pdf.

74 CIC, Guide to the Private Sponsorship, 11. See also CIC, Report on Plans and Priorities 2014-2015, 2.2.2.

75 Canadian Council for Refugees, "Important Changes."

76 "Global Consultations on International Protection, Strengthening and Expanding Resettlement Today: Challenges and Opportunities," 4th Mtg., EC/GC/02/7 (25 April 2002), para 5.

77 House of Commons Debates, 41st Parl, 1st Sess, No 248 (7 May 2013), 1840.

78 CIC, "Canada to Resettle 1,30o Syrian Refugees."

79 Canadian Council for Refugees, "CCR Responds to Government Announcement on Resettlement of Syrian Refugees" (8 July 2013).

80 Sponsorship from Turkey is now possible. CIC initiated a pilot project in 2014, extended through 2015, for sponsorship from Turkey. Refugee Sponsorship Training Program, "Guidelines on Sponsorship of Refugees out of Turkey," http://www.rstp.ca/en/refugee-sponsorship/ latest-policy-program-update/guidelines-turkey/.

81 Ashley Chapman, "Time for Canada to Step Up on Syrian Refugee Crisis, Now," Hill Times, 16 June 2014; Michael Swan, "Syrian Refugee Flow to Canada at a Trickle," Catholic Register, 26 June 2014.

82 Canadian Council for Refugees, "Canadian Immigration Responses to the Syrian Crisis: Backgrounder" (October 2013).

83 House of Commons Debates, (27 February 2014), 1500.

84 Alexis Pavlich, quoted in Debra Black, "Slow Progress Raises Doubts about Government's Syrian Refugee Pledge," Toronto Star, 18 March 2014.

85 Susana Mas, "Syrian Refugees: Canada Urged to Take In 10,000 by 2016," СвC News, 19 June 2014; Canadian Immigrant Settlement Sector Alliance, "CISSA-ACSEI Appeal to Minister Alexander" (4 June 2014).

86 Mas, "Syrian Refugees."
87 Xueting Zhao, "Syrian Refugees Waiting for Canada to Open the Door," Toronto Observer, 27 February 2014.

88 Michelle Zilio, "Canada Has Only Settled 'a Few' Government-Sponsored Syrian Refugees: Alexander," iPolitics, 5 March 2014.

89 Lina Dib, "Un Asks Ottawa to Open Its Doors for Refugees of Syria's Brutal Civil War," Canadian Press, 29 May 2014. In June 2014, both the director of the Syrian Canadian Council of Montreal and the sponsorship director of the Anglican United Refugee Alliance indicated that they had not heard of any of the 1,100 private sponsorship allotment actually arriving in Canada: "Syria's Refugees: Is Canada Keeping Its Promise? A Timeline of As It Happens Coverage," СBC, 26 June 2014 (June 12 audio), http://www.cbc.ca/radio/asithappens/thursdaysupreme-court-of-canada-first-nations-ruling-cbcstrategy-seasick-shark-fisherman-and-more-1.2903421/ syria-s-refugees-is-canada-keeping-its-promise-a-timeline-of-as-it-happens-coverage-1.2903424/.

90 CIC, "Processing Times for Privately Sponsored Refugee Applications" (22 July 2014).

91 Laura Lynch, "Syrian Refugee Applications Quietly Sped Up by Ottawa," свс News, 27 June 2014.

92 Foreign Affairs, Trade and Development Canada, "Helping to Protect the World's Most Vulnerable," news release, 7 January 2015.

93 Loly Rico, president, Canadian Council for Refugees, to Chris Alexander, minister of citizenship and immigration, "Letter concerning Resettlement of Syrian Refugees," 14 January 2015.

94 Gertrude Neuwirth and J. R. Rogge, "Canada and the Indochinese Refugees," in Indochinese Refugees: Asylum and Resettlement, ed. Supang Chantavanich and E. Bruce Reynolds (Bangkok: Institute of Asian Studies, Chulalongkorn University, 1988), 254.

95 Employment and Immigration Canada, "Private Sponsorship," 3.

96 Treviranus and Casasola, "Canada’s Private Sponsorship of Refugees Program," 180.

97 Canadian Council for Refugees, "The Private Sponsorship of Refugees Program: Current Challenges and Opportunities" (April 2006), 2.

98 Refugee Sponsorship Training Program, "Fact Sheet: Sponsorship Cost Table," March 2014, http://www.rstp.ca/ wp-content/uploads/2014/o3/Fact_Sheet_7_3_Sponsorship_Cost_Table_Sept2014.pdf.

99 UNHCR, "Nansen Refugee Award," http://www.unhcr.org/ nansen/503625396.html.

100 Australia, Commonwealth, Department of Immigration and Citizenship, "Australia's Humanitarian Program 201314 and Beyond," information paper (December 2012), 5.

101 Refugee Council of Australia, "Australia's Refugee and Humanitarian Program 2010-11: Community Views on Current Challenges and Future Directions" (February 2010), 3 . 
102 House of Commons Debates, 41st Parl, 1st Sess, No 248 (7 May 2013) 2000.

103 Steven Chase, "Canada to Boost Efforts to Help Syrian Refugees," Globe and Mail, 4 July 2014.

104 Ninette Kelley and Michael J. Trebilcock, The Making of the Mosaic: A History of Canadian Immigration Policy (Toronto: University of Toronto Press, 1998), 407.

105 “Onus Put on Public Groups, Ottawa Won't Sponsor More Refugees," Globe and Mail, 6 December 1979; Adelman, "Changes in Policy," 23.

106 "Ottawa Revamps Refugee Program, Increases 1980 Quota by 10,00o," Globe and Mail, 3 April 1980.

107 Dirks, "Policy within a Policy," 299.

108 See, for example, Laura Payton, "Election Issues 2015: A Maclean's Primer on Syrian Refugees," Maclean's, 3 September 2015; "Stephen Harper Suggests Canada Will Do More to Help Syrian Refugees," СвС News, 10 September 2015; Andy Blatchford, "Canada Election 2015: Syrian Refugee Crisis Re-emerges on Campaign Trail," Huffington Post Canada, 8 September 2015; "Election Primer: The Refugee Crisis, Four Things to Know before You Vote," Globe and Mail, 16 October 2015.

109 Liberal Party, "Syrian Refugees," https://www.liberal.ca/ realchange/syrian-refugees. The party platform did not attach a deadline to the commitment but the timeline was clearly put forward during the campaign. The New Democratic Party promised to bring 10,000 Syrian refugees to Canada by year end, and the Conservative Party promised to resettle 10,0oo Syrians by 2017.

110 Government of Canada, "Canada Offers Leadership on the Syrian Refugee Crisis," news release, 24 November 2015.

111 Ibid.

112 Joe Friesen, "Liberals Fall Short of Year-End Goal for Refugee Resettlement," Globe and Mail, 31 December 2015.
113 Government of Canada, "Canada Offers Leadership on the Syrian Refugee Crisis."

114 CIC, "Supplementary Information to the 2015 Immigration Levels Plan."

115 Ratna Omidvar, "Private Sponsors Build a Nation-and Leave a Legacy," Globe and Mail, 16 November 2015; Caroline Barghout, "Image of Alan Kurdi Dead on a Beach Moves Winnipeg Woman to Help Syrian Refugees," СвC News, 25 November 2015.

116 UNHCR, UNHCR Refugee Resettlement Trends 2015 (June 2015), 7.

117 Prime Minister of Canada, "Minister of Immigration, Refugees and Citizenship Mandate Letter," http://pm.gc. ca/eng/minister-immigration-refugees-and-citizenshipmandate-letter. On 16 December 2015 the Government of Canada announced that it would not pursue its appeal on the Interim Federal Health Program case and formally confirmed that all Syrian refugees, government and privately sponsored, were eligible for supplementary health coverage. Statement from the minister of immigration, refugees and citizenship, and the minister of justice and attorney general of Canada, Ottawa (16 December 2015); Government of Canada, "Interim Federal Health Program Coverage for Syrian Refugees," backgrounder, 16 December 2015.

118 Employment and Immigration Canada, Annual Report to Parliament: Immigration Plan for 1991-1995 Year Two (Ottawa: EIC, 1991), 22.

Shauna Labman is an assistant professor in the Faculty of Law at the University of Manitoba. She may be contacted at shauna.labman@umanitoba.ca. 